\title{
Possibilities to Assigning Meaning to Work beyond the Logic Disseminated by the Mainstream: A Study with Individuals that Work within Hip Hop Movement
}

\author{
Danielle de Araújo Bispo ${ }^{1}$, Débora Coutinho Paschoal Dourado ${ }^{1}$, Mariana Fernandes da Cunha Loureiro Amorim ${ }^{1}$ \\ \& Rita Rovai Castellan ${ }^{1}$ \\ 1 Federal University of Pernambuco-UFPE, Recife, Brazil \\ Correspondence: Mariana Fernandes da Cunha Loureiro Amorim, Federal University of Pernambuco-UFPE, \\ UFPE/ Centro de Ciências Sociais Aplicadas, CCSA, Departamento de Ciências Administrativas, Sala D-37. Rua \\ Professor Moraes Rego, 1235, s/n. Cidade Universitária, Recife, PE, Brazil. Tel: 55-819-309-8932. E-mail: \\ marifclamorim@gmail.com
}

Received: December 30, $2011 \quad$ Accepted: January 11, $2012 \quad$ Published: October 18, 2012

doi:10.5539/par.v1n1p85 URL: http://dx.doi.org/10.5539/par.v1n1p85

The research is financed by $\mathrm{CNPq}$ - Conselho Nacional de Desenvolvimento Cientifico e Tecnológico - "National Counsel of Technological and Scientific Development"

\begin{abstract}
This article explores the meaning that individuals involved with the Hip Hop attach to their work. The theoretical framework explores the meanings that work has acquired through history, especially in contemporaneity. A qualitative approach for investigation was adopted, with oral history as the major method of research. The selection of interviewees was based on the key informants' criterion. The data was analyzed through content analysis. Results obtained from this analysis were compared with the ethos developed by Bendassoli $(2007 ; 2009)$ about the meaning of work in contemporary society. The conclusion reached was that the meaning of work for the respondents is based on a romantic-expressive ethos. It is important to clarify that throughout life these individuals experienced or were exposed to more than one ethos.
\end{abstract}

Keywords: work, meaning of work, narratives, identities

\section{Introduction}

This article presents the meaning that individuals involved in a cultural sphere attach to their work. It is assumed that work does not exists only in the sense of employment, i.e., determined by organizational logic and formality (Organista, 2006). This research seeks to explore a logic of work that differs from the business logic. The primary assumptions of this investigation were: (i) there are alternatives to the organization of work beyond the ones offered by business models, and (ii) these alternatives may be present in the work within a cultural sphere.

The Hip Hop Movement was considered a fertile locus for this research. This finding emerged in part because of the available information about a movement named Rede de Resistência Solidária [Solidarity Resistance Network - SRN]. The SRN was created in 2005, proposing actions and art for communities in order to reflect about work and production in a collective way (Guimarães, 2007). During the research, it was noticed that the collective production has not had the desired success. Although the SRN is not the main focus of this study, it is the locale where were found people who make a living out of Hip Hop.

The Hip Hop movement, according to Queiroz (2008), has three modalities: a plastic, a scenic and a phonetic . The first is represented by graffiti painting on walls; the second refers to street dance and to the mime of break-dancers; and the third is characterized by the poetry of the Masters of Ceremony (MCs) and by the music of DJ's.

The movement, which originated en New York in the late 1970s, had social inclusion as one of its goals. Despite criticism that this proposal still presents today, it can be noticed that the culture is also incorporating an economic dimension. The production of rap music, for example, moves the market for CDs (Barreto, 2004). Some participants of the movement have emphasized the economic dimension as being important to professionalize the 
groups and for the control over the work and over what is produced. Barreto $(2004$, p. 87) presents the testimony of a member of the movement, KL Jay:

I see it in a positive light because the movement is growing. The groups are professionalizing and perceiving the hip hop movement as it should be seen, i.e as music, as talent, and as business as well. Like the administration of a company. Do not tell me that hip hop is just a cultural movement, because it isn't. Is also a trade. People buy clothes, CDs, Concerts tickets, etc. Money flows freely. Some groups are starting to have this perception [of the movement] as an enterprise and a business [...] (translated from Portuguese)

This quote illustrates how the economic rationality has entered the cultural sphere, whose base does not stem from the economic imperative and values. This, for Gorz (2003, p. 15) is named economicize, in other words is "including in the economic field what was previously excluded". This phenomenon is represented by the inclusion of the vocabulary typical of business administration in these individuals' arguments to justify certain actions or even to explain the organization of their work.

In contrast, other individual resist the values disseminated by the economic logic in order to maintain the critical and demanding tone of Hip Hop culture. In Recife, city located in the northeastern state of Pernambuco, the Collective Exxito de Rua and the Collective Nova Geração, groups that participate in SRN, seek to organize their work as a way to ensure financial support and maintain a critical and questioning proposal.

A passage written by Galo de Souza, a member of the Colletive Exito de Rua, and Carol Sena, in Salve S/A magazine (2009, p. 16), confirms this resistance

Walking through the city, we see billboards and advertisements of all consumer markets [...] Consumers buy and strive to obtain these products that pay for elite freedom. But grafitti artists [...] are the free expression, that are away from the system power, and can tell something [...] to show other possibilities to break the prison in our community

In order to show that possibilities beyond the economic logic for work are possible, the primary goals of this research is to analyze the meaning of work for individuals that act within hip hop movement. Thus, will answer the following investigative question: What is the meaning of work for individuals who work within the hip hop movement in the Rede de Resistência Solidária (SRN)?

The following sections gives an overview on the history of labor and, consequently, on the construction of individual's subjectivity through work. Then, the results will be presented and the main conclusions of the study will be discussed.

\section{The Meanings of Work}

Throughout human history, the work has acquired several meanings. This section will explore its meanings and configurations in various historical moments.

There are not many discussions about the meaning of work in the primitive mode of production. If it were possible to infer what was the meaning of work at that time it would probably be associated with the satisfaction of basic needs. According to Oliveira (1991), in this historical moment, the basic social relations were still being configured.

In ancient Greece, the work occupied a secondary place. Politics and philosophy were the valued activities (Albornoz, 2008). In this moment, it is not appropriated to talk about individuals defining their identities through work, "on the contrary, the description of the being did not connect to work, but rather to ethical and political ideals of the free citizen in the Polis" (Bendassoli, 2007, p. 37, translated from Portuguese)

In the Middle Ages, the work was subordinate to religion. In the beginning of this age work was seen as a punishment for $\sin$ (Albornoz, 2008), but was also as something in service of charity and health of the body and the soul (Tilgher; Mills apud Bendassolli, 2007, p. 44).

It is in the Renaissance that labor acquires value in and on itself, in other words, the meaning of work was no longer sought out of itself. In this moment, it's possible to talk about work valorization. "The ethic implicit in this tradition is based on the craft work model. In this model, "the worker and the product of his work are parts of the same set composed by the human as a creator" (Bendassolli, 2009, p. 17, translated from Portuguese).

The work became important for the definition of the individual identity within Protestantism. Calvino stated that no one could be sure of his own salvation and working was seen as a way to reduce this uncertainty (Anthony apud Bendassolli, 2007, p. 65). The work became an important fact for the evaluation of the moral status of a person. According to Bendassolli (2007, p. 68), in the Protestantism, there was a "compulsion to work, since idleness carried a burden of unbearable guilt" (translated from Portuguese). 
Nowadays, there are many approaches about work. Albornoz (2008) states that work is related to a purpose and an effort. Oliveira (1991) defines it as an activity performed by a man in which the goal is the production of wealth. Dejours (1992) establishes a connection between work and worker's mental life. Antunes (2003) presents an ontological definition, saying that work is the source that originated the social being, it is the first activity performed by men. Bendassolli (2009), presents an study on the meanings of work today and his contribution will be the most valued in the present study.

The work is studied from many different perspectives, but all of these ideas were complementary to this section. to expect a uniform definition of labor fails to account for the diversity in this thematic. After all, contemporarily, individuals attribute different meanings to work (Bendassoli, 2007, p. 2007, 2009), which can be a source either of suffering or of personal fulfillment.

The next section deals specifically with the meanings that work has acquired since Modernity until nowadays.

\section{The ethos of Bendassolli: Narratives about the Meaning and Value of Work in Contemporary.}

This section embraces concepts brought up in two of Bendassolli's books: Trabalho e identidade em tempos sombrios (2007) and Psicologia e Trabalho (2009). The aim here is to present the case of work in modernity and post-modernity and how it interfered in the construction of the subjectivity of individuals and in the perceptions that they hold about work.

It seems that the importance of work for the definition of individual identity was created by humans themselves in the modernity, specifically in eighteenth and nineteenth centuries. The result was the 'subject of work':

The subject of work is an instance that encompasses all human experiences through the sieve of work. As an ideal form, it presides the formations of the modern individual [...]. In other words, the subject of work, as presented by, Marx is a kind of anchor to describe who we are: individuals that work and whose sense of existence is largely extracted from the work. He builds this subjectivity from a new valorization of work and its meaning in the definition of the human existence (Bendassolli, 2009, p. 23)

In modernity, the meaning of work was presented through a social metanarrative; consequently, the individual narratives depended heavily on it. This metanarrative found support in the industrial society, which stressed the importance of work for the youth and preached its economic, moral, philosophical, ideological, and contractual centrality (Bendassolli, 2007). Thus, the author explains that:

The work was chosen as subject. In this position, it offered a social metanarrative about its social value and meaning, both for individuals and institutions. As a subject, in this philosophical sense, the work was the instance in which individuals became who they were (Bendassolli, 2007, p. 226, emphasis added by the author; translated from Portuguese).

In the twentieth century, changes occurred in the field of employment. There was a reduction in the amount of jobs, due to the insertion of technology in production; people expected less from work and started to build their identities through other areas of life (Bendassolli, 2009).

In the second half of twentieth century, the 'subject of work' weakens as element responsible for the definition of the individual's identity. Bendassolli recognizes this weakening, but insists that the importance of work did not completely disappear. What is characteristic of post-modernity, according to the author, is its ambiguity due to the multiplicity of meanings that work acquired. Thus, the identity of individuals is not defined solely by the work: "it is like if the work ceases to be the only possible objectification to the being, his only - or most privileged - form of revelation" (Bendassolli, 2007, p. 22).

To understand better the weakening of the relationship between work and identity, it is necessary to clarify the meaning of identity. Indentity has become the object of investigation over the last decades of twentieth century (Blustein apud Bendassolli, 2009). To Bendassolli (2007), identity is defined as a narrative that the individual builds throughout life. This narrative must be consistent and help one organize the meaning of existence. The author presents five public narratives about the meaning and value of work for contemporary individuals. He named them ethos. Ethos are identity narratives that act as "inventories of interpretations and meanings of work" (Bendassolli, 2009, p. 29), in which individuals construct and explain their identities, using one or more of these narratives as a basis. Table 1 summarizes the main features of these ethos.

The moral-disciplinary ethos is related to the Protestant ethic e to moral doctrines that advocate the traditional duty to work. The work has to do with responsibilities and with the completion of tasks regardless of the pleasure it involves. The individual identity is not necessarily related to work, and he is seen as someone who is simply fulfilling his duty (Bendassolli, 2007). 
On the other hand, the romantic-expressive ethos has as its main feature the work as an end in and on itself, i.e the work is recognized by both, the way it is done and the final product, but not by the salary or prestige.

In this ethos the work is important for the definition of identity [...] The problem is that, nowadays, it may be challenging, first because it is difficult for one to dedicate himself to a 'gift', a talent or a skill [...]; second, because of the consumerist greed that reaches the core of this ethos, redefining the meaning and value of the pleasure and satisfaction that arise from it (Bendassolli, 2007, p. 237, translated from Portuguese)

In the case of the Instumental ethos, work is seen in its liberal dimension, i.e, as an employment, as an exchange, submitted to the logic of capitalism. It has three features: (i) meritocracy dimension of work (meritocracy is a system in which justice emerges from merit, from the individual qualities); (ii) work as income obtainment, in other words, work is primarily capable of providing for consumerism; (iii) the work as status, which is determined by salary and position occupied within a company. In this ethos, the individual does not choose his work based on self-realization, but rather by the desire of status (Bendassolli, 2007).

Table 1. Ethos and work features

\begin{tabular}{ll}
\hline Types os ethos & Work features \\
\hline Moral-Disciplinary & $\begin{array}{l}\text { Public activity; social role; the identity (the true self) of the individual is not } \\
\text { associated with work; obligation. }\end{array}$ \\
Romantic-Expressive & $\begin{array}{l}\text { End in and on itself; seen as a gift, talent; recognized because of the final } \\
\text { product, not the salary; associated with identity. }\end{array}$ \\
Instrumental & $\begin{array}{l}\text { It is seen as a job, an exchange; has unstable bonds; the identity is not } \\
\text { associated with the work (unless it creates economic value); income } \\
\text { obtainment; meritocracy; status. }\end{array}$ \\
& $\begin{array}{l}\text { Ethics of pleasure; focuses on satisfaction; work for itself and for the ideals } \\
\text { of the subject; identity related to consumerism. }\end{array}$ \\
The person as a company itself; employment replaced by projects; Identity \\
Managerialist
\end{tabular}

Source: Based on BENDASSOLLI (2007)

In the consumerist ethos, the work is seen as a way to obtain satisfaction:

Identity is assumed depending on how much visibility, status and prestige this identity possesses, as well as consistency with the subjects identity ideals (of consumption) it brings. [...] someone works for himself and for his ideals and not for a collective ethic or ideal. In an extreme case, the concern is with the level of income and purchasing power that allow access to the market of consumer goods (Bendassolli, 2007, p. 246, translated from Portuguese)

Finally, the managerial ethos is connected to management or business management discourses and broadcasted by entrepreneurs. A widespread belief of this ethos is that the individuals should not look for jobs, because jobs are unstable. The concept of job is replaced by the concept of personal project. This ethos states that "work, career, success and failure, everything depends on the individual, who has to see himself as a company, as a entrepreneur of himself" (Bendassolli, 2007, p. 252-253, translated from Portuguese).

Bendassolli (2007) also states that none of the ethos would be capable of telling the ultimate truth about individuals They only function as narratives, offering values more or less consistent with the image that an individual has of himself. It is also important to note that individuals, in the construction of their identity within work, are exposed to more than one of these ethos.

Bendassolli's ideas, presented in this section, served as theoretical categories that permitted the study of work phenomenon for Hip Hop Movement members within the SRN.

\section{Methodology}

A qualitative approach of research was adopted, since it seems to best fit the understanding of social phenomena such as work and its meaning. This research is exploratory and descriptive (Richardson, 1999), since studies that 
investigate the meaning of work for individuals in the cultural field - particularly in Brazil - seem to be little explored in literature.

Though this approach allows for many methods, oral history was chosen because it assumes that understanding individuality is a way to observe the social reality (Goldenberg, 2000, p.36). Thus, the oral history seeks to investigate the facts and events that are recorded in the memory of prominent individuals in the community, being an extensive technique for data collection (Marconi and Lakatos, 2008).

Two individuals of the SRN were interviewed through this method: Galo, a member of the Collective Exxito de Rua, and Pixote, a member of the Collective Nova Geração. Both interviews occurred in January 2010.

On the February, 2011, we conducted an open interview with Galo. The open interview is a technique whose main purpose is exploratory. As stated by Boni and Quaresma (2005, p. 74) "the questions are answered in an informal conversation". The insertion of the newly collected data allowed to expand the analysis and to deepen the study of certain issues.

The choice of two individuals was based on key informant criterion, i.e individuals are chosen because of some characteristics that permit them to talk about the phenomenon in a richer and deeper way (Alvez-Mazzott; Gewandznajder, 2002). In addition, both respondents work with graffiti and music, making a living through these activities.

The data was analyzed through a content analysis method, in order to make inferences about the collected data through the "comparison of data obtained through speech and symbols, with the theoretical assumptions of different conceptions of world, individual, and society" (Franco, 2007, p. 31). The data obtained in the field were compared to the ethos developed by Bendassolli $(2007 ; 2009)$ about the meaning of work in contemporary society. The objective was to comprehend the meaning that these individuals attribute to their work.

The Table 2 contains a summary explanation of methods used in this study.

Table 2. Summary explanation of research methods used in the study

\begin{tabular}{lll}
\hline Research objective & Research method & Information's source \\
\hline Analyze the meaning of work & Oral History & Pixote \\
for individuals that make a & Oral History and open interview & Galo \\
living from Hip Hop & &
\end{tabular}

Source: The authors

\section{Data analysis}

The data analysis below, which came from samples based on both biographical methods and Oral History technique, could not have another format than the format of history in order to create a dialogue with the theory. In this section we tried to use "the lenses" of theory to see the reality. The story that will be told is the one about the life and work of two persons: Rooster and Pixote.

\subsection{The Meaning of work for Galo}

Galo had his first contact with graffiti as a child. Today, a little over thrity years old, he works with grafitti, paintings e music, making a living from these activities. He created the Collective Êxito de Rua in 2000, when he found in rap a form of expression. All activities that he develops are related to Hip Hop elements.

About his work experiences outside the field of culture, he said that as a child he sold newspapers and delivered medicine for a pharmacy. He worked almost three months in a company when he was older, but never had a formal contract. It can be noticed that his narrative does not have characteristics of an instrumental ethos, since he does not see himself looking for employment: "I never looked for a job, and I don't know, if I was going to look for it, I don't know how I would do it" (2010, translated from Portuguese). Rather, his opinion about the formal job market explicitly shows that either because of the difficulties to enter it or because he resists to its format and values, Galo did not want to undergo to this kind of market. His evalutation of the formal job shows awareness about its conditions:

There are very few jobs opportunities, the market is too small, the market is very tight, very competitive, very unfair, unjust, a lot of things that almost everyone knows. But options are created and it happens because there is 
space for that. Despite everything that exists in the world, things with solid foundation are continuously increasing (2010, translated from Portuguese).

His awareness about the onus involved in submitting to a formal job is emphasized when he says that he would only have a formal job if it was necessary to raise his son. "[...] For my son, I will do anything. But, Thank God,I don't need to. I have always been a promising bum" (2010, translated from Portuguese). When he talks about being a 'promising bum' it is possible to perceive that his intention is to say that he had never needed to submit to a formal job, because being outside of the formal job market (being a bum), never prevented him to progress on his work. Thus, the moral-disciplinary ethos that sees the work as a social role that the individual must perform was not observed in the interview.

Despite what has been said, Galo works for companies as well. He calls it 'commercial work'. His interview shows that this kind of job did not excite him. "I've already worked for many companies [...] I don't keep the work material for myself" (2010, translated from Portuguese). This year, it can be noticed a different attitude when he was asked about which work satisfies him more: the commercial work or the community work. He answered: "I'm satisfied with everything, nowadays. If I'm not satisfied, I don't do the work" (2011, translated from Portuguese). This reveals the submission to the demands of the job market as a way of earning money. This is understandable, since everyone needs to earn money in some way. Thus, through his work he does not seem to seek the wild pleasure preached by consumerist ethos. The money appears as more important for the growth of his work than for his personal satisfaction through consumption. The passage below reveals his satisfaction with the work and the need for money to invest in his work:

There are people that need to be paid to do something. I need to do what I need to do. If I don't do what I need, I think that is a greater problem than doing something that I've been paid for by someone else. (2010, translated from Portuguese)

There is always something, always need to spend money with equipment. I'm always buying equipment. Studio stuff. (2011, translated from Portuguese)

It can be noticed that in 2010, Galo presented a tougher discourse against the logic of the system, and he talked more about the community and the work he did for it and for the collective.

For some people that are studying or reading [about people like him], it is a beautiful history, but for the rest of the world it is crazy, like you dedicate your whole life to community work, without having a job, without accumulating any goods, without wanting a career, without worrying about anything (2010, translated from Portuguese).

This tone of resistance still exists in 2011, but it appears to be more associated with individual resistance.

Nowadays, something I think is different in Hip Hop is that it used to belong to a group, and now Hip Hop is something very individual. Not individual, because we are still talking about "us", still talking about street, still talking about everything. But it is individual in the sense that each person is fully responsible for his work (2011, translated from Portuguese).

His narratives became more individualistic probably because some actions that should be collective in the SRN, such as the collective production, did not work, or maybe because Galo is a father and wants to have more financial stability. However, the romantic-expressive ethos still seems to be more prevalent in Galo's discourse. Moreover, this ethos already assumes that the individual is dedicated to his gift: "[...] I started to make a living from what I did: selling shirts, painting shirts for skate shops, rock shirts, music groups' shirts, and I started to make some money with it" (2010, translated from Portuguese).

The respondent was provoked during the open interview to answer if he perceive his work as a business, since he sells canvas, makes concerts, gives receipts. His response shows that his work is not completely external to the market, but that it also is not dominated by the market's logic.

The business was born after, because when I started to paint there wasn't a business. I used to paint for free, taking a beating and running. Nowadays I paint and I receive money for that [...] I want this to grow. I don't want to be hided inside the community (2011, translated from Portuguese).

During both interviews with Galo, in 2010 and 2011, another characteristic of romantic-expressive ethos was confirmed: the identity construction. If today his work is individualized in some aspects that was not individual before, it is because some actions changed his context and identity. In 2010, Galo said: "[...] I live for my faith, for my beliefs, for what I want to do [...] sometimes I do things, then I read about the things I do and start to understand myself" (translated from Portuguese). In 2011, the respondent voiced a similar conclusion: "It's better to stay calm, do a conscious work, study. You have the essence of what you want to do" (translated from Portuguese). 
About the managerialist ethos, it is possible to notice, in 2011, a widespread discourse of the Business Administration field concerning both ideas and vocabulary that focuses on the individual as responsible for his success or failure: "This whole thing is becoming more individual in this sense [...] If everything goes wrong, it's your name on the fire line. If it goes well, it's in your name".

Given the history here reported, it is possible to notice some changes in the motivations of Galo regarding his work. In general, the work has a strong ideological basis for him. However, this ground is checkmated when his life story undergoes an inflection and he succumbs to the economic logic because of his human instincts of survival and protection. His strength, which was primarily political, is reduced to an individual dimension.

\subsection{The Meaning of work for Pixote}

Pixote had contact with graffiti only when he was sixteen years old. Nowadays, he is about thirty years old and makes a living from activities such as graffiti, painting, and music workshops. He created a group called Nova Geração, in 2007, which has a home studio. The group also participates in SRN, even though acknowledging that some of the activities it developed have weakened.

He had formal jobs experiences while still young, mostly because he married early and had to assume assume the expected role of breadwinner. About his first job, he says:

Since I got married very early [...] I had to support my family, I was very young, but I was the man. [...] We had our first son when I was 17 [...] I had to support my family and I started to work. My first formal job was as a janitor (2010, translated from Portuguese).

As it can be seen in the passage above, the respondent, at a certain point of his life, perceived a job as being his obligation, a role he should perform, based on the moral-disciplinary ethos. Also, this kind of work is named by him as "forced work". Moreover, he makes clear that he did not like this kind of work, i.e his identity was not associated to it, as it represented only an employment, characterizing the instrumental ethos.

I myself was forced to work on other things. I only finished high school [...] But then I worked as janitor, stamping shirts [...], as a salesman, and a lot of other things like that. But these jobs were, sincerely, to me, forced work because it was a work that I was doing just to earn money (2010, translated from Portuguese).

While working as a janitor and later as an employee in a clothing company, Pixote did graffiti as a hobby. He was latter fired from the clothing company. After looking for other jobs without success, decided to work on his own, painting shirts. With help from his mother-in-law, who gave him a room in her house, he started his own business: "I depended on myself, on my efforts, on my work. But there was a negative side. I worked... I woke up to paint [shirts], I slept to paint [shirts]. I used to spend all day painting and stay until dawn. I used to stop only when I was exhausted" (2010, translated from Portuguese). Thus, he tried to associate the business work format with the work for pleasure. In this way, the managerial ethos coexists with the romantic-expressive ethos. In this fragment, it is possible to see another way that Pixote perceives his work, through the managerial ethos. In this ethos, the individual is considered as a company, being responsible for his success or failure. For this reason he established his "productive process" in an intense way that was necessary to profitability.

The opportunity to work with graffiti arose when a professor asked if he had already ministered graffiti classes.

I liked the idea because art education could provide my self-sustainability and it was something I liked, I enjoyed seeing the kids learning something I taught them, something I learned alone [...] Any activity that I teach to a child or a teenager, makes me feel happy when I see that they want to learn and that they learn. (2010, translated from Portuguese)

It is only with this opportunity that Pixote starts to have a fulltime dedication to his work within the cultural sphere. Anyway, I searched for self-sustainability through art education because it was the most pleasant way to work, for me [...] Because you don't feel that you are working, you are enjoying (2010, translated from Portuguese).

It can be noticed that in this moment the work has another connotation, another meaning, being intimately related to pleasure, and also as a gift, a talent. Thus, the romantic-expressive ethos explains the meaning of work for Pixote today.

He also does 'commercial works', like Galo, to earn some money. This reveals, once more, how their work is not external to the market economy.

About the importance of the money and the financial returns he has in this work, he states: "We don't think about being rich, don't think about wasting a lot of money, but we want the necessary to survive, at least, with some 
dignity" (2010, translated from Portuguese). Thus, the consumerist ethos is not present in his discourse, since in this ethos the person values the purchasing power generated by his work.

To sum, even tough he lives in a capitalist society, Pixote's ethos seemed to remain unaffected by the contaminating process. He worked in a formal job, but still preserved his art and his involvement with the community, substantive elements of their relationship with work.

\section{Conclusions}

The analysis of the obtained data and the comparison to the various ethos allowed us to find in which narrative Galo's and Pixote's work is founded and to understand the meaning of work for them. It was possible to see that the work within Hip Hop culture cannot be free of relationships with the market. However it does not mean that the respondents agree with the values imposed by the market or that the meaning of work for these individuals must necessarily fit the logic of the mainstream.

The meaning of work for Galo and Pixote is grounded mainly on the romantic-expressive ethos. It is important to clarify that these individuals are influenced by the other narratives in various ways. Regarding Galo, it is possible to notice that managerial ethos goes along with the romantic-expressive ethos. However, the narrative that relates art and culture to work overlaps (and is stronger that) the narrative that relates work to business.

As for Pixote, it can be seen that he experimented with almost all narratives; i.e throughout his life, his work acquired several meanings. It was seen as an obligation (moral-disciplinary ethos), as an employment (instrumental ethos), and as a personal responsibility (managerial ethos). Regarding the consumerist ethos, it became clear that his work is not primarily associated with consumption.

The interest in understanding the meaning of work for individuals within a social movement arose as a way of exploring other possibilities to give meaning to work beyond the possibility disseminated by the mainstream logic. Other activities, outside of the formal job market, may guarantee the sustenance of individuals, such as Galo and Pixote, and in the meantime represent a resistance to the commodification of social relations.

However, it cannot be ignored that the work realized by these individuals, within a social movement sphere, can be characterized, according to some authors, as a precarious work, since they lack a work contract and the rights assured in a formal work relation (Organista, 2006).

In general, it was possible to observe that the work within a social movement is immersed in a dimension founded on pleasure, leisure, and in the indistinctness between work and life. Thus, the narratives of these Hip Hop movement members served to announce that the work they perform is different from the one typical of the economic model.

Finally, we urge other researchers to focus on individuals that act in organizations based on a diverse logic, in order to uncover other possibilities for work and life. Mainly, it is important to question the causes that determine the involvement of people in social movements, in order to reveal that other possibilities of work and life are possible.

\section{References}

Albornoz, S. (2008). What is work? São Paulo: Brasiliense.

Alves-Mazzotti, A. J., \& Gewandsznajder, F. (2002). Method on Social and Natural Sciences: qualitative and quantitative research. São Paulo: Pioneira Thomson Learning.

Antunes, R. (2003). The meanings of work: discussion about the affirmation and denial of work. São Paulo-SP: Boitempo editorial.

Barreto, S. G. P. (2004). Hip-Hop in Recife's metropolitan region: identification, cultural expression, and visibility. Unpublished thesis (M. A.): Federal University of Pernambuco, Brazil.

Bendassolli, P. F. (2007). Work and Identity in dark times: ontological insecurity in current work experience. Aparecida: Idéias \& Letras.

Bendassolli, P. F. (2009). Psychology and work: appropriations and meanings. São Paulo: Cengage Learning.

Boni, V., \& Quaresma, S. J. (2005). Learning to Interview: How to interview in Social Sciences. Eletronic Journal of Post-Graduation program in Political Sociology of UFSC, 2(3), 68-80.

Franco, M. L. P. B. (2007). Content Analysis. Brasília: Líber Livro Editora. http://dx.doi.org/10.1016/S0573-8555(06)82018-3

Goldenberg, M. (2000). The art of researching: How to make qualitative research in Social Sciences. Rio de Janeiro: Record. 
Gorz, A. (1982). Goodbye to proletariat: Besides socialism. Rio de Janeiro: Forense Universitária.

Guimarães, R. G. (2007). In the Cultural Policy field, the crabs with brains are organizing in order to disorganize. Unpublished thesis (M. A.): Federal University of Pernambuco, Brazil.

Marconi, M. A., \& Lakatos, E. M. (2008). Scientific Methodology. São Paulo: Atlas.

Martins, R. (2005). Hip Hop: A style that nobody controls. Santo André: Prima Línea ESETec.

Merriam, S. B. (1998). Qualitative research and case study applications in education. San Francisco: Jossey-Bass.

Oliveira, C. R. (1991). History of Work. São Paulo: Editora Ática.

Organista, J. H. C. (2006). The debate about centrality of work. São Paulo: Expressão Popular.

Queiroz, A., \& Silva, C. (2008). Recife African Nation: maracatu nação, capoeira, samba, afoxé, reggae and hip-hop. Recife: Catálogo da Cultura Afro-brasileira.

Souza, G. D., \& SENA, C. (2010). Collective action for graffiti. Revista Salve S/A, 1, 14-17.

United Nation Program for Development. (2003). Atlas of human development in Brazil. Retrieved October 7, 2010, from http://www.pnud.org.br/atlas/instalacao/index.php 